\title{
STRATEGI PENGEMBANGAN JAMU RAMUAN MADURA DI KABUPATEN SUMENEP
}

\author{
Ika Fatmawati $P^{1) *}$, Nur Qoudry Wijaya ${ }^{2)}$ \\ 1)* Fakultas Pertanian,Universitas Wiraraja \\ ${ }^{2)}$ Fakultas Ekonomi dan Bisnis, Universitas Wiraraja \\ email : $\underline{\text { ika agribisnis@yahoo.co.id }}{ }^{11^{* *}}$, qoudri@yahoo.co.id ${ }^{2)}$
}

\begin{abstract}
ABSTRAK
Salah satu daerah yang terkenal dengan brand jamu adalah Madura.Industri Jamu Ramuan Madura masih banyak memilki kendala di tengah keberhasilan yangtelah adakarena maraknya peredaran jamu berbahan baku kimia, dalam hal ini dikarenakan daya saing dan kemampuan nilai jual produk jamu dari usaha mikro yang belum terstandarisasi sesuai ketentuan Pembuatan Obat Tradisional yang Baik (CPOTB).Penelitian ini bertujuan untuk menentukan strategi pemasaran yang tepat terhadap produk jamu ramuan Madura berdasarkan studi perilaku konsumen.Untuk mengetahui strategi pemasaran yang tepat pada produk jamu ramuan Madura yaitu menggunakan analisis SWOT sebagai metode pengolahan data kemudian dipilah dalam IFAS dan EFAS 347, 62 dan 355 artinya faktor eksternal lebih kuat daripada faktor internal. Hasil penelitian berdasarkan skor IFAS dan EFAS. Strategi yang tepat untuk diterapkan pada produsen jamu Ramuan Madura yaitu: (a) Meningkatkan promosi dan memperluas daerah pemasaran Oleh karena ini untuk mengembangkan jamu ramuan Madura harus mampu memanfaatkan peluang pemasaran, (b) Modifikasi Kemasan, (c) Teknologi mengurangi aroma menyengat pada jamu, (d) adanya pelatihan dan pendampingan dalam mengurus ijin.
\end{abstract}

Kata Kunci :Jamu, Pemasaran, Strategi, SWOT

\section{PENDAHULUAN}

Jamu digunakan secara turun temurun yang merupakan warisan budaya bangsa.Bahan baku yang digunakan dalam pembuatan jamu tergolong dalamsepuluh komoditas tanaman obat yang potensial untuk dikembangkan. Industri jamu sangat berkontribusi besar pada pendapatan nasional, tersedianya lapangan kerja, dan peningkatan kesejahteraan masyarakat. Sekitar99\% bahan baku yang digunakan dari produk dalam negeri dinilai mampu memberikan multiplier effect cukup signifikan pada pertumbuhan perekonomian Indonesia dari sektor hulu (pertanian) hingga sektor hilir yang meliputi perdagangan dan perindustrian

Visi 2030 KADIN dan Road Map Industri Nasional merekomendasikan jamu sebagai klaster industri unggulan sebagai penurun angka kemiskinan, penggerak pencipta lapangan kerja, dan atas dasar kearifan lokal.Kementerian Koordinator
Bidang Ekonomi telah mencanangkan gerakan "Jamu Brand Indonesia" sebagai bagian dari kegiatan menyatukan merek jamu dalam satu payung Brand Indonesia.Di dalam dalam negeri penjualan jamu berpotensi hingga mencapai Rp. 20 triliun dengan ekspor senilai Rp. 16 triliun, sedangkan penjualan herbal dunia setiap tahun mencapai angka US\$60 miliar.Sebagai produsen jamu, Indonesia menduduki urutan keempat setelah China, India, dan Korea.

Salah satu daerah yang terkenal dengan brand jamu adalah Madura."Sumenep sebagai salah satu Kabupaten paling ujung timur di Pulau Madura telah lama mempraktekkan tumbuhan sebagai obat tradisional/jamu.Masyarakat Sumenep mempunyai kebiasaan minum jamu mengikuti prinsip "lebih baik tidak makan daripada tidak minum jam (Rifa'i, 2000). 
"Jamu ramuan Madura lebih dikenal untuk perawatan dan pengobatan terkait reproduksi wanita antara lain jamu perawatan tubuh, jamu mengencangkan payudara, jamu pasca melahirkan, jamu mempertahankan stamina, jamu sari rapat, dan lain sebagainya. Bentuk sediaan jamu terutama dalam bentuk pil kering atau pil dodol dan serbuk seduhan. Bentuk kapsul kurang diminati" (Lestari, dkk, 1998).

Jamu ramuan Madura menjadi alternatif pilihan masyarakat dari berbagai jenis jamu yang ada.Jamu ramuan Madura tidak hanya mengisi pasar daerah Madura, tetapi juga daerah luar Madura.Sebagian besar jamu ramuan Madura diproduksi oleh industri rumah tangga atau industri skala kecil.Agroindustri jamu ramuan Madura mampu memberikan kontribusi pendapatan bagi daerah (Fatmawati dan Amilia, 2017).

Industri Jamu Ramuan Madura masih banyak memilki kendala di tengah keberhasilan yangtelah ada. Maraknya peredaran jamu terbuat dari bahan kimia

\section{METODOLOGI PENELITIAN}

Lokasi penelitian ditentukan secara sengaja (purposive) yakni di empat kecamatan Kabupaten Sumenep (kota Sumenep, Manding, Kalianget, dan Saronggi) dengan mempertimbangkan bahwa Kabupaten Sumenep merupakan penghasil jamu ramuan Madura.

Pengambilan sampel pengembangan pasar menggunakan sampel informan kunci (key informan).Menurut Endraswara (2006), "Key Informan adalah orang atau sekelompok orang yang memiliki informasi pokok pada suatu objek tertentu". Dalam penelitian ini yang akan dijadikan sebagai key informan (informan kunci) adalah tenaga ahli, produsen jamu, masa kini semakin memprihatinkan dalam dekade lima tahun terakhir, karena berpotensi mencemari perkembangan jamu tradisional. Selain itu, banyak persaingan dan menurunnya citra jamu akibat dengan mudah ditemukannya produk jamu impor di pasar dalam negeri dapat memberikan dampak bagi industri skala menengah kebawah.Hal ini dikarenakan daya saing dan kemampuan nilai jual produk jamu dari usaha mikro yang belum terstandarisasi sesuai ketentuan Pembuatan Obat Tradisional yang Baik (CPOTB).

Saat ini daya beli masyarakat terhadap jamu khususnya jamu ramuan Madura menurun.Hal ini dapat dilihat beredarnya berbagai macam obat (jamu import dan farmasi) yang tersebar luas tampak lebih berhasil menarik minat masyarakat untuk dikonsumsi. Tujuan dari penelitian ini untuk mengetahui strategi pengembangan pasaryang tepat bagi produk jamu ramuan Madura berdasarkan studi perilaku konsumen.

kemudian konsumen dan non konsumen jamu ramuan Madura.

Sumber data menggunakan data primer dimana data didapat secara langsung dari responden jamu ramuan Madura dan pakar agribisnis, kemudian data sekunder yaitu data yang didapat dari studi pustaka/literatur terkait dan BPS kabupaten sumenep.Data didapat dengan metode observasi, wawancara, dan menyebar kuisioner.

Untuk menjawabtujuanpenelitian menggunakan analisis SWOT sebagai metode pengolahan data yang kemudian dipilah dalam IFAS dan EFAS. Berikut Tabel serta langkah-langkah dalam menentukan IFAS dan EFAS.

Tabel 3.1 Matrik IFAS (Internal Strategic Factor Analysis Summary)

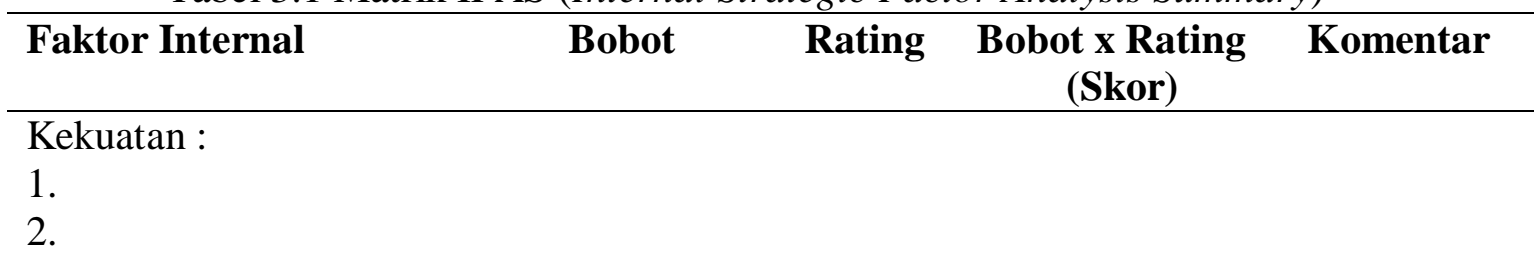


10.

Kelemahan :

1 .

2

10

Sumber: Rangkuti, 2006.

Tabel 3.2 Matrik EFAS (Eksternal Strategic Factor Analysis Summary)

\section{Faktor Internal}

Peluang :

1.

2 .

10.

Ancaman :

1 .

2

10.
Bobot Rating Bobot $x$ Rating Komentar

(Skor)

Sumber: Rangkuti, 2006.

Langkah-langkah:

1. Kolom 1: Susunlah 5-10 faktor kekuatan (Strenght), kelemahan (Weakness), peluang (Opportunity) dan ancaman (Threatment).

2. Kolom 2: Berikan bobot pada setiap faktor dimulai dari bobot 1,0 (sangat penting) hingga bobot 0,0 (tidak penting).

3. Kolom 3: Hitung rating untuk setiap faktor kekuatan dan peluang dengan memberi skala mulai dari 4 (outstanding) sampai dengan 1 (poor) berdasarkan pengaruh faktor terhadap kondisi perusahaan yang bersangkutan. Sedangkan, pemberian nilai rating pada kelemahan dan ancaman yaitu kebalikannya.

4. Kolom 4: Nilai bobot dikalikan pada kolom 2 dengan nilai rating pada kolom 3. Hasilnya berupa skor pembobotan untuk setiap faktor yang nilainya bervariasi mulai dari 4 (outstanding) sampai dengan 1 (poor).
5. Kolom 5: Untuk memberikan komentar atau catatan mengapa faktor-faktor tertentu dipilih dan bagaimana nilai pembobotannya dihitung.

6. Untuk memperoleh total skor pembobotan bagi perusahaan dengan cara skor pembobotan (kolom 4) dijumlahkan. Nilai total ini menunjukkan bagaimana perusahaan bereaksi terhadap faktor-faktor eksternal dan eksternal.

7. Kolom ke-5 digunakan untuk memberikan komentar atau catatan mengapa faktor-faktor tertentu dipilih dan bagaimana nilai pembobotannya dihitung.

8. Untuk memperoleh total skor pembobotan pada perusahaan, jumlahkan skor pembobotan (kolom 4). Nilai total ini menunjukkan bagaimana perusahaan bereaksi terhadap faktor eksternal dan eksternal. 
Setelah mengetahui posisi perusahaan, langkah berikutnya adalah melakukan formulasi alternatif strategi dengan matriks SWOT. Hasil dari matriks ini akan menghasilkan empat strategi. Berikut gambar matriks SWOT:

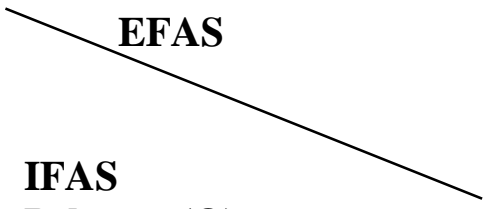

Peluang (O)

- Menentukan Faktor Eksternal

Ancaman (T)

- Menentukan faktor Eksternal

Sumber: Rangkuti, 2006

Tabel 3.3 Matriks SWOT

Kekuatan (S)

- Menentukan

Faktor Internal

Strategi (SO)

\section{Kelemahan (W)}

5-10 - Menentukan 5-10 Faktor

Kekuatan Kekuatan Internal

\section{Strategi (WO)}

Strategi yang menggunakan Strategi yang meminimalkan

5-10 kekuatan dan memanfaatkar kelemahan dan peluang peluang memanfaatkan peluang

Strategi (ST)

5-10 Strategi yang menggunakan kekuatan dan mengatasi ancaman

\section{Strategi (WT)}

Strategi yang meminimalkan kelemahan dan menghindari ancaman

\section{PEMBAHASAN}

Hasil analisis Swot dilakukan FGD dengan dengan penjual jamu dan pakar agribisnis melakukan diskusi untuk menemukan titik permasalahan dan strategi apayang tepat untuk mengatasinya yang dihadapi penjual jamu agar dapat meningkatkan penjualan.

\section{A. Lingkungan Internal dan Eksternal \\ 1. Faktor Internal}

\section{a) Kekuatan}

- Bahan baku yang berlimpah untuk pembuatan jamu ramuan Madura

Banyaknya permintaan jamu ramuan Madura membutuhkan bahan baku yang berlimpah pula, sehingga Kabupaten Sumenep menjadi salah satu faktor kekuatan dalam aktivitas industri jamu di Madura. Bahan baku menjadi tombak pertama berjalannya suatu produksi. Di Sumenep bahan baku untuk jamu sangat melimpah sehingga sudah dapat memenuhi kebutuhan dalam produksi jamu.

- Kepercayaan masyarakat akan jamu ramuan Madura

Sejak dahulu nenek moyang kita sudah memperkenalkan ramuan mujarab yang dapat mengurangi rasa sakit, mencegah terserang penyakit, mengobati sakit flu, dan lain sebagainya yaitu jamu yang diracik dari berbagai tumbuhan-tumbuhan alam (daun, bunga, buah, akar, batang, dsb) yang sangat berkhasiat untuk menjaga kesehatan. Sehingga sudah terbukti mengonsumsi dalam jangka panjang sangat baik karena tidak mengandung bahan kimia. Sehingga timbul kepercayaan masayarakat akan khasiat jamu ramuan Madura. Sehingga menjadi peluang untuk menarik konsumen karena faktor kepercayaan masyarakat akan khasiat jamu Ramuan Madura.

- Jamu ramuan Madura sudah terkenal secara turun temurun

Jamu merupakan warisan budaya bangsa Indonesia, berupa ramuan bahan tumbuhan obat sudah digunakan secara turun temurun yang terbukti aman dan mempunyai manfaat bagi kesehatan sehingga menjadi kekuatan karena dari turun temurun sudah terbukti khasiaatnya.

- Alami tanpa campuran bahan kimia Jamu berasal dari ekstrasi bagian tanaman yaitu batang, daun, bunga, 
buah, atau akarnya yang memiliki segudang khasiat untuk menyembuhkan sakit sehingga menjadi kekuatan bagi industri jamu terus berkembang untuk mempertahankan kealamiannya.

- Kualitas Pelayanan yang Baik Konsumen jamu akan merasakan puas jika mereka memperoleh pelayanan yang baik dan sesuai yang diharapkan oleh konsumen jamu karena salah satu elemen penting yang menjadi pertimbangan utama konsumen jamu dalam suatu pembelian produk adalah adanya Kualitas Pelayanan yang Baik, baik dari segi fisik, jasa, kualitas jamu, dan pelayanan penjual yang dapat dinilai secara obyektif sebelum dan sesudah melakukan pembelian. Hal tersebut menjadi kekuatan jamu Ramuan Madura karena dapat kualitas jamu dapat diukur dengan melihat hal hal yang berkaitan dengan pelayanan baik sebelum dan sesudah membeli jamu baik mulai segi fisik, kemampuan pelayanan, bukti pelayanan, jaminan pelayanan, dan lain sebagainya.

\section{b) Kelemahan}

- Sebagian besar jamu ramuan Madura tidak memiliki ijin produksi dan ijin edar.

Jamu ramuan Madura belum memiliki ijin edar dikarenakan produknya yg tidak tahan lama karena tidak menggunakan pengawet.Sehingga menjadi kelemahan bagi industry jamu untuk menembus pasar modern dan mengekspornya.

- Belum ada kandungan yang pasti seusai Uji Laboratorium

Menurut Fujiastuti menilai, dirinya tidak dapat memastikan takaran yang tepat untuk seseorang meminum jamu karena belum pernah dilakukan penelitian sebelumnya.Setiap orang juga memiliki kebiasaan yang berbeda saat mengkonsumsi
jamu.Pada produk jamunya sendiri juga tidak disebutkan berapa banyak takaran bahan yang digunakan serta efek samping usai meminumnya.Padahal ini berpengaruh pada jumlah dan frekuensi minum. "Berapa banyak kunyit, berapa banyak asam, berapa banyak diminum per hari. Belum ada penelitian yang mengatakan jika kita minum kunyit asem, kunyitnya lima gram, asamnya lima gram sehingga jamu belum ada kandungan yang pasti”

- Efek samping penggunaan jamu

Sebagai minuman tradisional, jamu dinilai sebagai obat herbal untuk kesehatan tubuh.Jamu sendiri memiliki ragam seperti beras kencur, kunyit asem, temulawak, pahitan, cabe puyang hingga uyupuyup.Pembuatan jamu memang menggunakan bahan dasar dari rempah-rempah dan akar-akaran seperti kunyit, jahe, asam, sirih, pahitan sampai gula Jawa.Jadi dipastikan minum jamu dalam takaran yang secukupnya tidak berlebihan.Bahwa minum jamu juga harus punya takarannya sendiri. Dengan kata lain, minum jamu tak bisa disamakan seperti minum air putih yang bisa dinikmati setiap saat.

- Bentuk dan kemasan jamu masih sederhana

Kunci pemasaran suatu produk yaitu dari bentuk dan kemasan yang menarik juga dapat meyakinkan konsumen, konsumen juga yakin bahwa produknya aman. Jamu ramuan Madura masih dikemas menggunakan botol aqua bekas air minum. Tidak ada kemasan khusus dan menarik .

- Rasa jamu yang pahit dan aroma jamu menyengat

Mayoritas kebanyakan orang tidak suka minum jamu karena rasanya yang pahit dan aroma jamu yang kurang enak.Sehingga dijaman 
sekarang masyarakat kurang berminat mengonsumsi jamu.Mereka lebih suka minum obat yang tidak ada rasanya ketimbang minum jamu.Obat juga praktis dan mudah untuk di dapatkan.

\section{Faktor Eksternal}

\section{a) Peluang}

- Perubahan paradigma terhadap jamu Dijaman pandemi covid-19 ini masyarakat kebanyakan beralih pada jamu, karena jamu dipercaya mampu menangkal virus corona.Masyarakat cenderung beralih mengonsumsi pada obat-obatan yang alami yaitu jamu ramuan Madura karena juga baik untuk jangka panjang.

- Era pandemi permintaan jamu meningkat

Permintaann jamu sejak pandemi covid-19 meningkat karena msyarakat ingin menjaga kesehatannya, minum jamu dapat menjaga kekebalan tubuh.Sejak wabah COVID-19 menyerang, segala produk dengan klaim pencegahan dan penyembuhan laris manis di pasaran, tak terkecuali ragam ramuan Madura seperti jahe, kunyit, asam jawa, dan temulawak. Mereka percaya jamu tersebut dapat meningkatkan daya tahan tubuh sehingga bisa menangkal transmisi virus corona.

- Pemasaran terpadu

Pemasaran terpadu saat ini sudah jadi tolak ukur untuk mengembangkan pemasaran jamu ramuan Madura dikarenakan konsumen dapat melihat secara langsung proses produksi jamu sekaligus menyediakan tempat wisata agar konsumen dapat menikmati jamu sambil menikmati pemandangan sehingga konsumen minum jamu sambil liburan. Untuk itu pemasaran selain dikembangkan secara offline juga dapat dilakukan secara online.Jadi teknik pemasaran terpadu yaitu dengan mendatangkan konsumen, meyakinkan konsumen, dan dapat menarik minat pembeli sehingga hal ini dapat jadi peluang untuk meningkatkan pemasaran terpadu.

- Inovasi jamu ramuan Madura

Semakin banyaknya persaingan maka industri jamu mampu bersaing dan menginovasi produk jamu, dari segi bahan, kualitas, sterilisasi proses jamu, bentuk jamu, dan memperbaiki kemasan jamu. Sehingga hal ini menjadi peluang untuk pengembangan jamu ramuan Madura karena hal ini sangat penting untuk mempertahankan konsumen, inovasi produk jamu mampu mengurangi rasa bosan pada jamu.Karena sifat konsumen yang selalu tertarik pada kemasaran terbaru.

- Petani menjadi mitra homeindustri jamu Ramuan

Kebutuhan bahan baku dapat terpenuhi dengan cara bermitra dengan petani, karena akan mampu memberikan kualitas standart bahan yang akan digunakan. Petani tidak bingung mengenai modal untuk menanam, dan produsen dapat memenuhi permintaan.

\section{b) Ancaman}

- Persaingan dengan obat kimia

Obat kimia atau farmasi sudah memiliki pangsa pasar yang baik, masyarakat dengan mudahnya mendapatkan obat kimia. Masyarakat juga dengan mudahnya percaya akan khasiat obat farmasi, dan percaya obat farmasi dapat memberikan efek yang cepat.

- Tuntutan daya beli masyarakat

Tuntutan daya beli masyarakat menjadi ancaman pada industry jamu ramuan Madura dikarenakan jamu ramuan Madura jika tidak lgsung habis maka akan kadaluarsa, karena masa simpannya yang relative cepat.

- Kurangnya perhatian pemerintah terhadap pengembanganindustri jamu Pemerintah kurang memperhatikan pengembangan industri jamu, hal tersebut dapat dilihat industri jamu 
belum sejajar dengan obat farmasi.Seperti halnya pasal 27 Undang-undang Kesehatan Nomor 23 yang mendefinisikan obat tradisional sebagai pengobatan di luar ilmu kedokteran atau keperawatan.Hal ini membuat industri jamu kesulitan untuk memberikan resep sebagai pengobatan.

- Fluktuasi harga bahan baku

Kenaikan bahan baku dapat meresahkan produsen karena akan mempengaruhi keuntungan dan harga jual jamu. Sedangkan konsumen untuk jamu sangat enggan untuk mengeluarkan gocek yang cukup mahal. Sehingga naiknya harga akan dapat mempengaruhi permintaan konsumen terhadap jamu.

- Pesaing jamu sejenis

Seiring berkembangnya zaman, semakin banyak bermunculan usaha jamu sejenis yang akan bersaing sehingga hal ini menjadi ancaman. Karena konsumen yang mempunyai sifat ingin mencoba hal baru akan beralih pada produk baru. Terlebih jika dari segi harga, rasa, kualitas jamu mampu bersaing.

- Terdapat Medis belum menerima jamu sebagai alternative pengobatan pasiennya.
Hal ini menjadi ancaman, dikarenakan sekarang dunia tidak memprioritasnya pengobatan secara tradisional, rekomendasi dokter cenderung menggunakan obat kimia.Karena menurut dokter sari dari racikan jamu bisa membahayakan ginjal. Begitu juga saat ibu hamil tidak disarankan minum jamu dikarenakan nantii pengaruh buruk ke bayinya akan seperti lebam saat baru lahir.

\section{B. Strategi yang Tepat Pengembangan PasarJamu Ramuan Madura Guna Meningkatkan Penjualan \\ 1) Penentuan Bobot IFAS \& EFAS}

Penentuan Bobot Analisis Lingkungan Internal (IFAS) dan Analisis Lingkungan Eksternal (EFAS).Berdasarkan analisis lingkungan internal dan eksternal, maka langkah selanjutnya ialah penentuan bobot matrik SWOT.Bobot matrik SWOT diperoleh dari penentuan faktor-faktor analisis lingkungan internal (Strength, Weakness) dan eksternal (Opportunity, Threats) yang lebih urgen, kemudian dijumlahkan dan dipersentase.Penentuan bobot dari analisis lingkungan internal (Strength, Weakness) dan eksternal (Opportunity, Threats) dapat dilihat dari tabel berikut.

Tabel 4.23

Penentuan Bobot Analisis Lingkungan Internal (IFAS)

\begin{tabular}{|c|c|c|c|c|c|c|c|c|c|c|c|c|c|}
\hline \multirow{2}{*}{\multicolumn{2}{|c|}{ ALI }} & \multicolumn{10}{|c|}{ Faktor yang Lebih Urgen } & \multirow{3}{*}{$\begin{array}{c}\text { JUMLAH } \\
6\end{array}$} & \multirow{3}{*}{$\begin{array}{c}\text { BOBOT } \\
14,29\end{array}$} \\
\hline & & \multirow{2}{*}{ A } & \multirow{2}{*}{$\frac{\mathrm{B}}{\mathrm{A}}$} & \multirow{2}{*}{$\frac{\mathrm{C}}{\mathrm{C}}$} & \multirow{2}{*}{$\frac{\mathrm{D}}{\mathrm{A}}$} & \multirow{2}{*}{$\frac{E}{E}$} & \multirow{2}{*}{$\begin{array}{l}\mathrm{F} \\
\mathrm{A}\end{array}$} & \multirow{2}{*}{$\frac{G}{A}$} & \multirow{2}{*}{$\frac{\mathrm{H}}{\mathrm{A}}$} & \multirow{2}{*}{$\begin{array}{l}\mathrm{I} \\
\mathrm{A}\end{array}$} & \multirow{2}{*}{$\frac{\mathrm{J}}{\mathrm{J}}$} & & \\
\hline \multirow{5}{*}{ Strength } & $\mathrm{A}$ & & & & & & & & & & & & \\
\hline & $\mathrm{B}$ & A & & $\mathrm{C}$ & $\mathrm{B}$ & B & B & B & $\mathrm{B}$ & B & B & 7 & 16,67 \\
\hline & $\mathrm{C}$ & A & B & & $\mathrm{D}$ & $\mathrm{C}$ & $\mathrm{C}$ & $\mathrm{C}$ & $\mathrm{C}$ & $\mathrm{I}$ & $\mathrm{J}$ & 4 & 9,52 \\
\hline & $\mathrm{D}$ & $\mathrm{D}$ & B & $\mathrm{C}$ & & $\mathrm{D}$ & $\mathrm{D}$ & $\mathrm{D}$ & $\mathrm{D}$ & $\mathrm{I}$ & D & 5 & 11,90 \\
\hline & $\mathrm{E}$ & $\mathrm{E}$ & $\mathrm{B}$ & $\mathrm{C}$ & $\mathrm{D}$ & & $\mathrm{E}$ & $\mathrm{E}$ & $\mathrm{E}$ & $\mathrm{E}$ & $\mathrm{J}$ & 5 & 11,90 \\
\hline \multirow{3}{*}{ Weakness } & $\mathrm{F}$ & A & $\mathrm{B}$ & $\mathrm{C}$ & $\mathrm{F}$ & $\mathrm{E}$ & & G & $\mathrm{H}$ & I & $\mathrm{J}$ & 1 & 2,38 \\
\hline & $\mathrm{G}$ & A & B & $\mathrm{C}$ & G & $\mathrm{E}$ & $\mathrm{F}$ & & $\mathrm{G}$ & I & $\mathrm{J}$ & 2 & 4,76 \\
\hline & $\mathrm{H}$ & A & B & $\mathrm{C}$ & D & $\mathrm{E}$ & $\mathrm{F}$ & $\mathrm{H}$ & & I & $\mathrm{J}$ & 1 & 2,38 \\
\hline
\end{tabular}




\begin{tabular}{|c|c|c|c|c|c|c|c|c|c|c|c|c|c|}
\hline & I & A & I & C & I & I & I & I & I & & J & 6 & 14,29 \\
\cline { 2 - 10 } & J & A & J & C & J & E & J & J & J & I & & 5 & 11,90 \\
\hline \multicolumn{10}{|c|}{ TOTAL } \\
\hline
\end{tabular}

Sumber : Data Primer diolah 2020

Tabel 4.24

Penentuan Bobot Analisis Lingkungan Eksternal (EFAS)

\begin{tabular}{|c|c|c|c|c|c|c|c|c|c|c|c|c|c|}
\hline \multirow{2}{*}{\multicolumn{2}{|c|}{ ALI }} & \multicolumn{10}{|c|}{ Faktor yang Lebih Urgen } & \multirow{3}{*}{$\begin{array}{c}\text { JUMLAH } \\
4\end{array}$} & \multirow{3}{*}{$\begin{array}{c}\text { BOBOT } \\
11,11\end{array}$} \\
\hline & & \multirow{2}{*}{$\mathrm{A}$} & \multirow{2}{*}{$\frac{B}{A}$} & \multirow{2}{*}{\begin{tabular}{l|}
$\mathrm{C}$ \\
$\mathrm{A}$
\end{tabular}} & \multirow{2}{*}{\begin{tabular}{l|}
$\mathrm{D}$ \\
$\mathrm{D}$
\end{tabular}} & \multirow{2}{*}{$\begin{array}{l}\mathrm{E} \\
\mathrm{A}\end{array}$} & \multirow{2}{*}{\begin{tabular}{l|}
$F$ \\
$E$
\end{tabular}} & \multirow{2}{*}{\begin{tabular}{|c|}
$G$ \\
$F$ \\
\end{tabular}} & \multirow{2}{*}{$\begin{array}{l}\mathrm{H} \\
\mathrm{G}\end{array}$} & \multirow{2}{*}{$\begin{array}{l}\mathrm{I} \\
\mathrm{H}\end{array}$} & \multirow{2}{*}{\begin{tabular}{|l|}
$\mathrm{J}$ \\
$\mathrm{A}$
\end{tabular}} & & \\
\hline \multirow{5}{*}{ Strength } & A & & & & & & & & & & & & \\
\hline & $\mathrm{B}$ & B & & B & B & $\mathrm{E}$ & $\mathrm{F}$ & $\mathrm{G}$ & $\mathrm{H}$ & $B$ & $\mathrm{~J}$ & 4 & 11,11 \\
\hline & $\mathrm{C}$ & $\mathrm{C}$ & $\mathrm{B}$ & & $\mathrm{D}$ & $\mathrm{C}$ & $\mathrm{G}$ & $\mathrm{C}$ & $\mathrm{C}$ & $\mathrm{C}$ & $\mathrm{C}$ & 6 & 16,67 \\
\hline & $\mathrm{D}$ & $\mathrm{D}$ & $\mathrm{B}$ & $\mathrm{D}$ & & $\mathrm{D}$ & $\mathrm{D}$ & G & $\mathrm{D}$ & D & $J$ & 5 & 13,89 \\
\hline & $\mathrm{E}$ & $\mathrm{E}$ & $\mathrm{B}$ & $\mathrm{C}$ & $\mathrm{D}$ & & $\mathrm{F}$ & $\mathrm{G}$ & $\mathrm{H}$ & $E$ & $E$ & 3 & 8,33 \\
\hline \multirow{5}{*}{ Weakness } & $\mathrm{F}$ & $\mathrm{F}$ & $\mathrm{B}$ & $\mathrm{C}$ & $\mathrm{D}$ & $\mathrm{F}$ & & $\mathrm{F}$ & $\mathrm{H}$ & $\mathrm{F}$ & $\mathrm{F}$ & 5 & 13,89 \\
\hline & G & A & G & $\mathrm{C}$ & $\mathrm{D}$ & $\mathrm{G}$ & $\mathrm{F}$ & & $\mathrm{H}$ & G & $\mathrm{J}$ & 3 & 8,33 \\
\hline & $\mathrm{H}$ & A & B & $\mathrm{C}$ & $\mathrm{D}$ & $\mathrm{H}$ & $\mathrm{F}$ & G & & $\mathrm{H}$ & $\mathrm{J}$ & 2 & 5,56 \\
\hline & $\mathrm{I}$ & A & $\mathrm{B}$ & $\mathrm{C}$ & $\mathrm{D}$ & $\mathrm{E}$ & $\mathrm{F}$ & $\mathrm{G}$ & $\mathrm{H}$ & & $\mathrm{J}$ & 0 & 0 \\
\hline & $\mathrm{J}$ & $\mathrm{J}$ & B & $\mathrm{J}$ & $\mathrm{D}$ & $\mathrm{J}$ & $\mathrm{F}$ & $\mathrm{G}$ & $\mathrm{H}$ & J & & 4 & 11,11 \\
\hline \multicolumn{12}{|c|}{ TOTAL } & 36 & \\
\hline
\end{tabular}

Sumber : Data Primer diolah (2020)

2) Penentuan Skor Analisis Lingkungan

Internal (ALI) dan Analisis Lingkungan Eksternal (ALE)

Penentuan skor analisis lingkungan internal (Strength, Weakness) dan eksternal (Opportunity, Threats) diperoleh dari hasil kali bobot dan rating. Rating diperoleh dari penentuan nilai rating yaitu nilai $5=$ sangat berpengaruh, 4 = berpengaruh, 3 $=$ cukup berpengaruh, $2=$ kurang berpengaruh, dan $1=$ tidak berpengaruh. Penentuan skor dari analisis lingkungan internal (Strength, Weakness) dan eksternal (Opportunity, Threats) dapat dilihat dari tabel berikut.

\section{Tabel 4.25}

Matriks Analisis Lingkungan Internal (ALI)

\begin{tabular}{lccc}
\hline \multicolumn{1}{c}{ Faktor Internal } & \multirow{2}{*}{ Bobot } & \multirow{2}{*}{ Rating } & \multirow{2}{*}{ Skor } \\
\cline { 5 - 5 } Kekuatan & & 4 & 57,14 \\
1. Bahan baku yang berlimpah untuk pembuatan jamu & 14,29 & & 5 \\
ramuan Madura & & 53,33 \\
2. Kepercayaan masyarakat akan jamu ramuan Madura & 16,67 & & 28,57 \\
3. Jamu ramuan Madura sudah terkenal secara turun & 9,52 & 3 & 35,71 \\
$\quad$ temurun & 11,90 & 3 & 35,71 \\
4. Alami tanpa campuran bahan kimia & 11,90 & 3 & 240,48 \\
5. Kualitas pelayanan yang baik & 64,29 & &
\end{tabular}




\section{* Kelemahan}

1. Sebagian besar jamu ramuan Madura tidak memiliki ijin produksi dan ijin edar

$\begin{array}{ccc}2,38 & 1 & 2,38 \\ & & \\ 4,76 & 2 & 9,52 \\ 2,38 & 1 & 2,38 \\ 14,29 & 4 & 57,14 \\ 11,90 & 3 & 35,71 \\ 35,71 & & 107,14 \\ 100 & & 347,62\end{array}$

Sumber : Data Primer diolah (2020)

Hasil penelitian menunjukkan bahwa terdapat lima kekuatan dan lima kelemahan pada strategi penjualan jamu ramuan Madura. Faktor kekuatan terbesar sesuai dengan skor terbesar Kepercayaan masyarakat akan jamu ramuan
Maduradengan skor 83,33. Kelemahan terbesar bentuk dan kemasan sederhana dengan skor 57,14, sehingga jamu ramuan Madura kurang diminati oleh para non konsumen. Hal tersebut akan berpengaruh pada perkembangan pemasaran jamu ramuan Madura.

Tabel 4.26

Matriks Analisis Lingkungan Eksternal (ALE)

\begin{tabular}{|c|c|c|c|}
\hline Faktor Eksternal & Bobot & Rating & Skar \\
\hline Peluang & Bodod & Kating & SKOr \\
\hline 1. Perubahan paradigma terhadap jamu & 11,11 & 3 & 33,33 \\
\hline 2. Era pandemi permintaan jamu meningkat & 11,11 & 3 & 33,33 \\
\hline 3. Pemasaran terpadu & 16,67 & 5 & 83,33 \\
\hline 4. Inovasi jamu ramuan Madura & 13,89 & 4 & 55,56 \\
\hline 5. Petani menjadi mitra homeindustri jamu Ramuan & 8,33 & 3 & 24,99 \\
\hline Total faktor-faktor peluang & 61,11 & & 230,56 \\
\hline * Ancaman & & & \\
\hline 1. Persaingan dengan obat kimia & 13,89 & 4 & 55,56 \\
\hline 2. Tuntutan daya beli masyarakat & 8,33 & 3 & 24,99 \\
\hline $\begin{array}{l}\text { 3. Kurangnya perhatian pemerintah terhadap } \\
\text { pengembanganindustri jamu }\end{array}$ & 5,56 & 2 & 11,12 \\
\hline 4. Fluktuasi harga bahan baku & 0 & 1 & 0 \\
\hline $\begin{array}{l}\text { 5. Terdapat Medis belum menerima jamu sebagai } \\
\text { alternative pengobatan pasiennya. }\end{array}$ & 11,11 & 3 & 33,33 \\
\hline Total faktor-faktor peluang & 38,89 & & 125 \\
\hline Total Peluang dan Ancaman & 100 & & 355 \\
\hline
\end{tabular}

Sumber : Data Primer diolah 2020

Hasil penelitian menunjukkan bahwa terdapat lima peluang dan lima ancaman pada strategi penjualan jamu ramuan Madura. Faktor peluang terbesar sesuai dengan skor terbesar Kepercayaan masyarakat akan jamu ramuan Madura dengan skor 83,33. Ancaman terbesar persaingan dengan obat kimia dengan skor 55,56, dikarenakan mempunyai efek lebih cepet menyembuhkan, sudah teruji secara klinis, sudah memiliki ijin edar sehingga mayoritas tenaga medis menyarankan obat kimia sebagai alternative penyembuhan ketika sakit.

Berdasarkan tabel 4.25 total skor ALI adalah 347,62dan dan tabel 4.26 total skor ALE adalah 355 Hal ini berarti bahwa faktor internal lebih kuat daripada faktor eksternal. Oleh karena Pengembangan jamu ramuan Madura harus mampu memanfaatkan peluang 
yang dimiliki serta mengatasi kelemahan yang sangat berpengaruh terhadap penjualan jamu ramuan Madura.

\section{3) Analisis Matriks Posisi SWOT}

Berdasarkan hasil analisis yang telah dilakukan sebelumnya oleh peneliti, faktor internal dan eksternal yang dihadapi produsen jamu ramuan Madura dapat dikombinasikan kedalam matriks posisi SWOT.Untuk mengetahui posisi penjualan jamu ramuan Madura pada saat ini melalui matriks posisi SWOT.

Perhitungan skor total dari analisis lingkungan internal (ALI) yang terdiri atas kekuatan dan kelemahan dengan skor total sebesar 347,62 sedangkan pada skor total dari analisis lingkungan eksternal (ALE) yang terdiri atas peluang dan ancaman dengan skor total sebesar 355. Dari skor yang diperoleh, kemudian dimasukkan pada diagram matriks posisi SWOT, sehingga bisa diketahui gambaran posisi strategi pengembangan pasar yang tepat bagi produk jamu ramuan madura berdasarkan studi perilaku konsumenberada di kuadran I (agresif) artinya pengembangan pasar jamu ramuan Madura guna meningkatkan penjualan berarti mempunyai beberapa faktor kekuatan dan peluang yang cukup besar. Seperti halnya menurut penelitian Salsabila dan Supriana (2018) yang berjudul "Strategies to increase the consumption of traditonal medicine in Medan" bahwasanya Kuadran I adalah situasi yang paling menguntungkan, yang berarti bahwa perusahaan memiliki peluang dan kekuatan sehingga bisa memanfaatkan kekuatan dan peluang. Strategi Kekuatan-Peluang yang digunakan yaitu:

1. Memanfaatkan ketersediaan bahan baku untuk meningkatkan ketersediaan obat tradisional

2. Memanfaatkan ketersediaan tenaga kerja untuk meningkatkan ketersediaan obat tradisional

3. Mengoptimalkan pengetahuan pelaku usaha pengobatan tradisional untuk meningkatkan kualitas

Hight

355

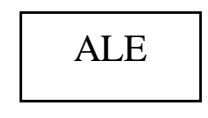

西

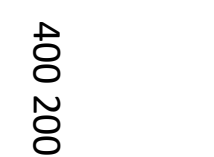

Kuadran 3

Kuadran 1

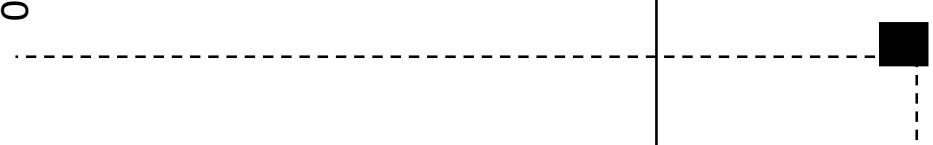

\section{i}

Kekuatan

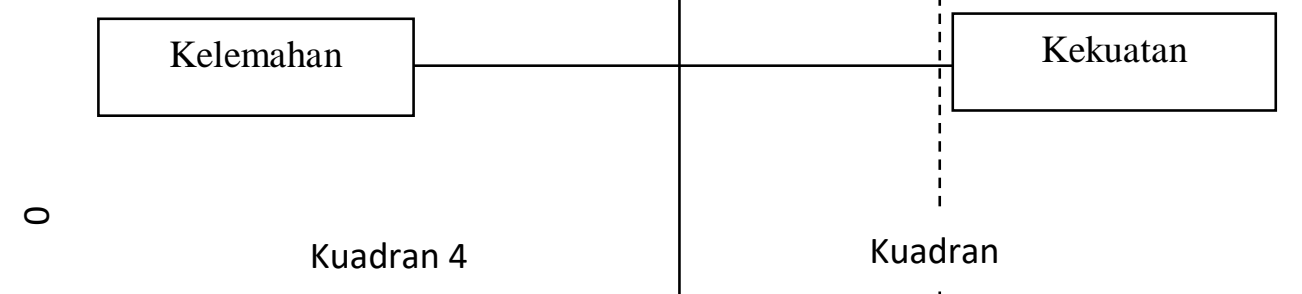

0

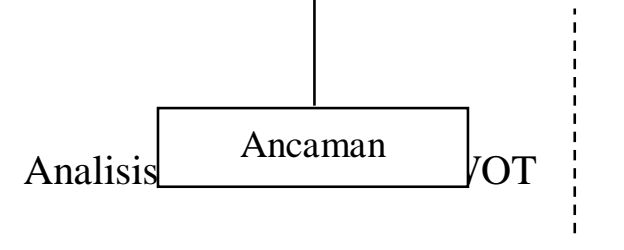

Formulasi Strattyı

Low Hight 
Strategi yang sesuai dengan situasi lingkungan internal dan eksternal pengembangan jamu Ramuan Madura dibawah ini :

\begin{tabular}{|c|c|c|}
\hline ALE & $\begin{array}{l}\text { Strengths }(\boldsymbol{S}) \\
\text { 1. Bahan baku yang } \\
\text { berlimpah untuk } \\
\text { pembuatan jamu ramuan } \\
\text { Madura } \\
\text { 2. Kepercayaan masyarakat } \\
\text { akan jamu ramuan } \\
\text { Madura } \\
\text { 3. Jamu ramuan Madura } \\
\text { sudah terkenal secara } \\
\text { turun temurun } \\
\text { 4. Alami tanpa campuran } \\
\text { bahan kimia } \\
\text { 5. Kualitas pelayanan yang } \\
\text { baik }\end{array}$ & $\begin{array}{l}\text { Weaknesses }(\boldsymbol{W}) \\
\text { 1. Sebagian besar jamu ramuan } \\
\text { Madura tidak memiliki ijin } \\
\text { produksi dan ijin edar } \\
\text { 2. Belum ada kandungan yang } \\
\text { pasti seusai Uji } \\
\text { Laboratorium } \\
\text { 3. Efek samping penggunaan } \\
\text { jamu } \\
\text { 4. Bentuk dan kemasan masih } \\
\text { sederhana } \\
\text { 5. Rasa jamu pahit dan aroma } \\
\text { menyengat }\end{array}$ \\
\hline $\begin{array}{l}\text { Opportunities }(\boldsymbol{O}) \\
\text { 1. Perubahan paradigma terhadap } \\
\text { jamu } \\
\text { 2. Era pandemi permintaan jamu } \\
\text { meningkat } \\
\text { 3. Pemasaran terpadu } \\
\text { 4. Inovasi jamu ramuan Madura } \\
\text { 5. Homeindustri jamu bermitra } \\
\text { dengan petanitanaman herbal } \\
\end{array}$ & $\begin{array}{l}\text { Strategi S-O } \\
\text { 1. Menpertahankan serta } \\
\text { meningkatkan kualitas } \\
\text { 2. Memperluas jaringan } \\
\text { pemasaran } \\
\text { 3. Memperkuat kemitraan } \\
\text { dengan petani tanaman } \\
\text { herbal }\end{array}$ & $\begin{array}{l}\text { Strategi W-O } \\
\text { 1. Modifikasi kemasan } \\
\text { 2. Teknologi mengurangi } \\
\text { aroma menyengat pada jamu } \\
\text { 3. Pendampingan ijin produksi } \\
\text { dan ijin edar }\end{array}$ \\
\hline $\begin{array}{l}\text { Threaths }(\boldsymbol{T}) \\
\text { 1. Persaingan dengan obat kimia } \\
\text { 2. Tuntutan daya beli masyarakat } \\
\text { 3. Kurangnya perhatian } \\
\text { pemerintah terhadap } \\
\text { pengembangan industri jamu } \\
\text { 4. Fluktuasi harga bahan baku } \\
\text { 5. Terdapat Medis belum } \\
\text { menerima jamu sebagai } \\
\text { alternative pengobatan } \\
\text { pasiennya. }\end{array}$ & $\begin{array}{l}\text { Strategi S-T } \\
\text { Memaksimalkan } \\
\text { Kekuatan untuk } \\
\text { Mengurangi Ancaman } \\
\text { 1. Meningkatkan kualitas } \\
\text { jamu ramuan Madura } \\
\text { 2. Adanya pelatihan pada } \\
\text { home industri jamu } \\
\text { tepat komposisi dan } \\
\text { tepat dosis jamu. } \\
\text { 3. Diservikasi bentuk jamu } \\
\text { Ramuan Madura }\end{array}$ & $\begin{array}{l}\text { Strategi W-T } \\
\text { Meminimalkan Kelemahan } \\
\text { untuk Mengurangi Ancaman } \\
\text { 1. Meningkatkan promosi dan } \\
\text { memperluas daerah } \\
\text { pemasaran } \\
\text { 2. Meningkatkan kemitraan } \\
\text { dengan industri jamu herbal } \\
\text { 3. Meningkatkan hubungan } \\
\text { dengan pemerintah maupun } \\
\text { lembaga lain } \\
\text { 4. Adanya pelatihan dan } \\
\text { bimbingan dalam mengurus } \\
\text { ijin }\end{array}$ \\
\hline
\end{tabular}

\section{Gambar 2}

Diagram Matriks SWOT

\section{a. Strategi}

1) Strategi SO

- Mempertahankan serta meningkatkan kualitas

Memasuki rana dunia perdagangan bebas, kita akan menemukan berbagai jenis produk dijual
dipasaran.Konsumen mempunyai beberapa alternatif agar kebutuhannya terpenuhi. Produsen yang mampu berdaya saing akan selalu eksis untuk berkompetensi di dunia persaingan yang ketat. Kualitas produk adalah salah satu dari lima 
keunggulan kompetitif yang dapat dipergunakan untuk unggul dalam persaingan bisnis. Dengan kualitas produk yang tinggi dapat dipergunakan sebagai senjata ampuh untuk menang dalam persaingan.

- Memperluas Jaringan Pemasaran Pada era modern ini media elektronik menawarkan kemudahan untuk memperluas jaringan pemasaran jamu ramuan Madura. Sosial media seperti facebook, instagram, shopee, dan whatsaap, buka lapak, JD.Id dan lain sebagainya mempermudah pengguna mencari produk yang diinginkan. Dengan memperluas jaringan pemasaran berpeluang untuk membuat usaha jamu ramuan Madura berkembang di Kabupaten Sumenep.

- Memperkuat Kemitraan dengan Petani Tanaman Herbal

Kemitraan dengan petani merupakan suatu kerja sama antara produsen jamu dengan petani tanaman herbal, pola pembinaan yang diterapkan mulai dari bagaimana mengolah lahan, memilih bibit, teknik budidaya, sistem tanam, pengendalian hama penyakit, hingga pasca panen, sehingga anatara produsen jamu dan Petani saling smembutuhkan, saling menguntungkan, dan saling ketergantungan dengan tujuan menggandeng petani herbal guna meningkatkan kualitas dan kuantitas jamu ramuan Madura sehingga jadi peluang agar jamu ramuan Madura dapat berkembang dengan bermitra mampu dalam pemenuhan bahan sesuai prinsip Good Agricultural Practice (GAP).

2) Strategi WO

- Modifikasi Kemasan

Hal utama yang menjadi sorotan pada produk adalah kemasan, kemasan yang menarik dapat menarik konsumen.Kemasana jamu juga dibuat bervariasi ukurannya agar konsumen dapat memilih untuk membeli produk yang ukuran berapa.Sehingga hal tersebuat pemasarannya dapat dijangkau semua kalangan dari kelas menengah kebawah sampai menengah ke atas.

- Teknologi Mengurangi Aroma Menyengat Pada Jamu

Jamu identik dengan aromanya yang khas dimana orang yang mau minum jamu pasti menyumbat hidung karena aromanya tidak enak.Sehingga diperlukan teknologi mengolah jamu agar aromanya tidak menyengat sehingga konsumen maupun non konsumen tidak enggan untuk meminum jamu karena aroma.

- Pendampingan Ijin Produksi dan Ijin Edar

Di era modern ini sudah banyak produk tiruan, produk abal-abal yang diedarkan sehingga ada ketakutan pada konsumen untuk mengonsumsi produk yang tidak mempunyai ijin produksi dan ijin edar.Sehingga ijin produksi dan ijin edar untuk memasarkan jamu ramuan Madura sangat penting untuk kepercayaan masyarakat. Konsumen tidak akan ragu jika jamu Ramuan Madura mempunyai ijin produksi dan ijin edar.

\section{3) Strategi ST}

- Meningkatkan kualitas jamu ramuan Madura

Kepercayaan konsumen jangan sampai dirusak karena produsen yan mengurangi kualitas bahan yang digunakan untuk memproduksi jamu, dengan alasan harga bahan baku naik atau untuk meminimalkan biaya pengeluaran produksi. Karena hal tersebut membuat usaha tidak akan bertahan lama.

- Adanya pelatihan pada home industri jamu tepat komposisi dan tepat dosis jamu

Kebanyakan produsen jamu ramuan Madura kurang memperhatikan komposisi yang tepat dan berapa 
dosis jamu yang di anjurkan. Karena banyak orang beranggapan jamu alami tanpa bahan kimia tidak akan overdosis jika mengonsumsi banyak. Untuk itu penting adanya pelatihan pada produsen jamu dalam merekomendasikan dosis jamu yang akan dikonsumsi konsumen.

- Diservikasi Bentuk Jamu Ramuan Madura

Dalam dunia usaha perlu adanya diservikasi produk karena dilihat dari persepsi non konsumen dengan alasan tidak mengonsumsi jamu ramuan Madura karena tidak terbiasa, alasan kedua karena rasanya tidak enak, dan berbagai alasan lainnya.Sehingga diservikasi produk jadi strategi untuk pengembangan jamu ramuan Madura guna mendongkrak penjualan pada non konsumen jamu Ramuan Madura.Contoh diservikasi produk yaitu kopi lengkuas berdasarkan penelitian di dapatkan kalau pemasaran produk kopi lengkuas berpotensi hal tersebut dapat dilihat berdasarkan aspek penawaran dan permintaan memiliki prospek yang baik untuk tahun 2016 - 2020 karena terjadi surplus (kelebihan) permintaan. Penawaran kopi lengkuas mengalami deficit (kekurangan) sehingga belum memenuhi permintaan padatahun 2016-2020 sebesar $6.786 .804,800 \mathrm{~kg}$ (Rahman, dkk. 2018).

4) Strategi WT

- Meningkatkan Promosi dan Memperluas Daerah Pemasaran

Penjualan jamu ramuan Madura akan meningkat dengan digencarkan promosi agar semua orang tahu produk apa yang ditawarkan, hal tersebut juga dapat memperluas daerah pemasaran jamu ramuan Madura.

- Meningkatkan kemitraan dengan industri jamu herbal
Kemitraan pada industri jamu herbal dijadikan strategi untuk meningkatkan pengembangan jamu Ramuan Madura.Karena industri jamu herbal sudah besar dapat dijadikan mitra terlebih pada masa pandemi saat ini permintaan jamu ramuan Madura meningkat sehingga produsen jamu dapat menjadi pemasok untuk memenuhi permintaan jamu yang kian meningkat.

- Meningkatkan Hubungan dengan Pemerintah maupun lembaga lain Pemasaran pada suatu produk tidak lepas dari peran serta pemerintahan, salah satu strategi yang perlu dilakukan oleh produsen jamu ramuan Madura yaitu dengan meningkatkan penjualan dan penggunaan jamu, karena peran pemerintahan saat kuat dalam memperluas jaringan pemasaran.Karena selama ini pemerintahan belum secara optimal dalam pengembangan jamu ramuan Madura.

- Adanya pelatihan dan Pendampingan dalam mengurus ijin

Adanya pelatihan dan pendampingan untuk mengurus ijin sangat membantu para produsen jamu di Madura, karena masih banyak yang belum paham dan kebanyakan karena persoalan adminitrasinya yang lumayan ribet yang membuat produsen jamu enggan mengurus ijin

\section{KESIMPULAN}

Dari hasil analisis matriks ALI dan ALE, Kepercayaan masyarakat akan jamu ramuan Madura dengan skor 83,33. Kelemahan terbesar bentuk dan kemasan sederhana dengan skor 57,14 Faktor peluang terbesar sesuai dengan skor terbesar Kepercayaan masyarakat akan jamu ramuan Madura dengan skor 83,33. Ancaman terbesar persaingan dengan obat kimia dengan skor 55,56, Posisi Pengembangan Pasar Jamu Ramuan 
Madura Guna Meningkatkan Penjualan berada pada kuadran I. Strategi yang perlu diterapkan produsen jamu ramuan Madura mendukung kebijakan pertumbuhan yang agresif (growth oriented strategy). Strategi yang tepat untuk diterapkan pada produsen jamu Ramuan Madura yaitu: (a) Meningkatkan promosi dan memperluas daerah pemasaran, (b) Modifikasi Kemasan, (c) Teknologi Mengurangi Aroma Menyengat Pada Jamu, (d) adanya pelatihan dan pendampingan dalam mengurus ijin.

\section{DAFTAR PUSTAKA}

Aditama. 2014. Jamu \& Kesehatan.

Badan Penelitian dan Pengembangan

Kesehatan:Jakarta

Gunarsa, Singgih D. 2008.Psikologi anak : Psikologi Perkembangana anak dan Remaja.PT.BPK Gunung Mulia: Jakarta

Fatmawati, I., \& Destryana, A. (2017). The prospects of jamu agro-industry as a herbal agribusiness in Sumenep. EProceeding Stie Mandala, 657-668. http://jurnal.stiemandala.ac.id/index.php/eproceeding/ article/view/155

Handayani, L. 2003. Membedah Rahasia Ramuan Madura. Agromedia Pustaka

Lestari, Handayani. Suharmiati. Suharti Sakiro. Badrijah Djoerban. K. R. Sogijono dan Setia Pranata.1998. Inventarisasi Jamu Madura yang Dimanfaatkan untuk Pengobatan atau Perawatan gangguan Kesehatan Berkaitan dengan Fungsi Reproduksi
Wanita. Buletin Penelitian Sistem Kesehatan. Volume 2 Nomor 1

Rangkuti, Freddy.2006. Analisis SWOT Teknik Membedah Kasus Bisnis. Jakarta: PT. Gramedia Pustaka Utama.

Rifa'i.2000.Pingit,Pijet,dan Pepahit:Peran Tumbuhan dalam Kosmetik Tradisional Indonesiaseperti dicerminkan di Daerah Madura

Sudarmin. Asyhar, Rayanda. 2012.

Transformasi Pengetahuan Sains Tradisional menjadi Sains Ilmiah dalam proses Produksi Jamu Tradisional. Edu-Sains Journal. Volume 1: Hal 1-7

Ujang Sumarwan. 2011. Perilaku

Konsumen Teori dan Penerapannya dalam Pemasaran.PT Ghalia Indonesia: Jakarta

William J. Stanton. 1991. Prinsip Pemasaran.Hal 5.Erlangga : Jakarta

Winarsa, Hendra. 2019.Strategi Pengembangan Jamu Kemasan Di Indonesia.Jurnal MADANI Vol.2 No.1. Hal (131 - 144)

Prastiwi, W. D., \& Setiyawan, H. (2016). Perilaku Konsumsi Susu Cair Masyarakat Di DaerahPerkotaan Dan Pedesaan (Milk Consumption Behavior of Urban and Rural Communities). Agriekonomika, 5(1), 41.https://doi.org/10.21107/agriekono mika.v5i1.996 